\title{
Legal Scope of the Mediation and Problem of Applicability
}

\author{
Sandra Kaija ${ }^{1}$, Inga Kudeikina ${ }^{2}$
}

\begin{abstract}
Mediation can be described as a multi-functional legal tool serving the mission of law, which is to ensure public balance, justice and order. This is possible owing to the legal nature of mediation, because it is essential not to merely solve a dispute but to understand its cause during the mediation process. Nowadays, mediation is equally effective in cases associated with civil disputes and criminal offences to attain understanding-based reconciliation between the victim and the perpetrator. However, the voluntary nature of mediation may hinder the achievement of a positive result in some situations. The aim of this article is to examine the legal scope of mediation with a view to determining to which extent mediation can be applied in civil and criminal proceedings and answering the question of whether possibilities offered by mediation are effectively used by law. The added value of mediation is the alignment of parties' interests by means of active cooperation and the elimination of the cause of the dispute. Contrary to enforcement mechanisms, such as the execution of court rulings, mediation enables more effective use of possibilities provided by law as a social system and alleviation of tension caused by disputes in society. This research employs general scientific methods, such as analysis, induction and deduction and interpretation of law. The research is based on legislation, scientific literature and case-law.
\end{abstract}

Keywords: Mediation, criminal proceedings, civil proceedings, settlement and resolution of disputes

\section{Introduction}

Disputes and specific disagreements is a natural component of legal relationships, considering that fact that it is almost implausible to ideally relate different interests of right holders. To resolve civil disputes and disagreements, constitutional rights are used, specifically, the right to have a case heard in court. According to statistics, there were 36777 civil cases (court statistics on civil cases in 2016) and 10744 criminal cases (court statistics on criminal cases in 2016) received by the Courts of First Instance in Latvia in 2016. Also law scientists point to contemporary public dependence on legal proceedings (Esplugues: 2015). In cases of committed criminal offences the court solves civil claims and decides on the perpetrator's punishment. In criminal procedure it is crucial that the victim receive both financial and moral satisfaction, whereas the perpetrator the adequate punishment, which would allow him to understand the casual relationship between the committed offence and the punishment and which would direct the perpetrator to real improvement.

Because the court decision must be carried out as forced enforcement, the primary objective of the court is to settle the disputes and strike settlements, which could be conditional and unrelated to parties' understanding of dispute causes and without real

| ${ }^{1}$ Head of the Doctoral Study Program "Law", Riga Stradiņš University, Professor, Expert of the Latvian Council of Science, Member of the Working Group of the Ministry of Justice for amendments to the Criminal Procedure Law

| 2 Assistant Professor of Riga Stradins University 
wish to settle disagreements. Forced enforcement is an advantage of the court decision, yet, it also represents a weakness because it manifests the formality of the ruling. Parties can comply with the court ruling due to respect but also because of real understanding of the ruling and own free will. In the long-term it will be the parties' free will, which is considered during the dispute settlement, which will prevent the dispute from further reoccurrence. Therefore, it is important to use legal instruments that incorporate parties' wish as a component in dispute settlement.

The dispute settlement process which considers the parties' interests and which offers solutions based on relating parties' interests is called mediation. According to some scientific claims, mediation offers advantages in comparison to court proceedings (Аенисенко, 2010). Despite having positive contributions in dispute settlements, mediation cannot be considered as panacea because its application is limited by parties' wishes and parties' wishes to settle the dispute in a consensual manner.

By considering the role of mediation in the rights system, the aim of the paper is to examine legal framework of mediation in conjunction with rights doctrine in order to evaluate the admissibility of mediation in civil and criminal proceedings and to provide recommendations pertinent to the expansion of application contexts for mediation. Application of mediation should be supported because it allows for court resources to be used more effectively, while reducing social tensions.

The study employs general scientific research methods and the methods of law interpretation; it is also based on research of legislation and literature review.

\section{Research}

The legal status of mediation in dispute settlement is determined in several acts of legislation. In Latvia since 18 June 2014 the Mediation Law (Mediācijas likums:2014) has been enforce based on European Parliament and Council Directive Nr.2008/52/EK of 21 May 2008 on specific aspects of mediation in civil cases and commercial matters (Direktivva Nr.2008/52/EK: 2008). In relation to civil disputes the legal framework is defined in the Law of Civil Procedure (Civilprocesa likums:1998). The analysis of the rule of law allows to conclude that mediation as a legal instrument is assigned to the out-ofcourt tools of dispute settlement. Mediation represents typical diversity of forms and procedures and lack of strict conditions (Аболонин, 2014). The opportunity to use free forms for dispute settlements, which are neither time- nor premisis-restricted, is not connected to the direct precence of state power and allows the involved parties to get untied, openly express own opinion un reveal concealed interests.

In mediation the defined component is the content, not the form. What is important is to attain the result - dispute settlement; what is less important is the types of means (excluding, certainly, illegitimate means such as threats, deceit and coercion) used to achieve this result. Evaluating the mediation limits of admissibility in civil law, it should be concluded that they are not limited. Traditionally mediation is applied to family, inheritance, work and commercial disputes. In private law this enumeration cannot be exhaustive because the private law principles allow for wide freedom of actions for right holders, including the choice of the type of dispute settlement. According to Russian law scientist Vadims Abolonins, in scientific literature there is some view consistently with 
which in comparison to law, a dispute that was settled through mediation might not be fair because mediation allows to diverge from objective determination of the truth (Аболонин, 2014). This opinion can be evaluated critically. Mediation is not arbitrariness. The mediation procedure itself, rights and duties of the involved parties and other procedural questions are strictly regulated in legislation. In the achieved settlement, legal content is not defined. Therefore, parties are given legal freedom pertaining to the content of decision. This is in common with the aim of the Mediation Law consistently with which it is important to promote harmonization of social relationships. Observing the principle of the civil law, all is allowed that is not prohibited by law and therefore the parties can reach a settlement based on a consensual decision, which is closer to the spirit of the law rather than the wording. This would not be considered a disadvantage if this were the way to achieve the court objective, specifically, reaching peaceful resolution of legal relations. A similar conclusion is made based on Article 19 of Directive Nr.2008/52/EK, which clearly states that mediation should not be considered as worse alternative to the legal procedure. Quite to the contrary, Directive Nr.2008/52/EK encourages initiatives aimed at ensuring that the settlement reached in writing as a result of mediation should be executable by the parties involved, the except being the cases when its content is contradictory to legislation. It is important to stress that the concept of "contradictory to legislation" is not the same as "does not match the legislation." Linguistically, these concepts are similar; however, each has its own legal content. For example, creditors can refuse to demand late payment fee. Such plaintiff's action does not match the demands outlined in the law (Paragraph 1 of Article 1759 of the Civil Law provides for the duty of late payment (Civillkums:1993), however, this will not be in contradiction with legislation. The right holders have the right not to use their subjective rights.

The starting points of mediation can be very different. Any disagreement might be possible to resolve through mediation. A dispute might be settled prior to claim submission to court and even civil case submission to court is not an obstacle for mediation. Literature offers a variety of classification types depending on different criteria. One of such criteria is the "initiator's" criterion consistently with which mediation can be voluntary, or the one initiated by the parties involved, or can be recommended by court. The court rights to suggest mediation are defined in Article 17 of the Mediation Law and Part 2 of Article 147 of the Civil Procedure Law. The court recommended mediation as a term has entered the legal language. However, not all law scientists agree with this, pointing to the fact that the term is in contradiction with the free choice of mediation (Тихонова, 2010). It should be stressed that the court recommendation cannot be interpreted as a forced measure because all mediation principles apply also to mediation recommended by court, including freedom or free will. Court recommends but does not force its will. Therefore, there are no obstacles for referring to the court recommended mediation. The court recommended settlement is similarly created (Part 2 of Article 183 of the Civil Procedure Law), when prior to the completion of court hearing, the court clarifies if the parties are interested in reaching a settlement. In both cases the court performs an advisory function, which is naturally included into the legal procedure aim - settle the dispute.

As a result of the development of civil procedural rights, the court recommended 
mediation is reinforced in the Civil Procedure Law. Upon the Mediation Law coming into effect on 18 June 2014, the relevant amendments were made to the Civil Procedure Law, obliging the court not only to prepare the case for hearing but also obliging it to offer the parties involved the opportunity to settle the dispute via mediation during the court proceedings. The situation can be evaluated as positive when the parties involved are encouraged to settle the dispute via mediation being offered an opportunity to receive $50 \%$ of paid state duty back.

Mediation has productively been used in disputes between familiar persons and in cases when disputes have deep and personal roots, for example, they can be family disputes, disputes about inheritance parts, commercial disputes and disputes among co-owners. Settling disputes via mediation would be useful in the long-term because it would ensure that the parties not only settled the dispute but also understood the deeper causes of the conflict and therefore would be able to prevent it from re-emergence in future. The key objective of mediation is to help the parties involved to find a mutually acceptable solution independently of others (Trosens, Vanaga: 2006). It should be noted that "the involvement of a mediator will not only help to resolve a particular dispute but will also serve the function of a dispute prevention instrument in the long-term" (Kudeikina: 2012); mediation within the framework of civil rights relationships is considered a universal rights instrument and its usage is not restricted. Also, the British law scientist Bryan Clark indicates that the use of mediation by courts should become an independent and widely used legal institute (Clark:2012). The court recommended mediation opportunities in civil proceedings are not yet fully used.

The mediation opportunities in Latvia are connected to mediation becoming obligatory in dispute settlement at the pre-trial stage. Scientific literature points to both benefits and weaknesses of such a system (Esplugues: 2015). Undoubtedly mediation is not a universal dispute settlement instrument, which will always yield positive outcomes; however, one cannot deny that there are no side effects in the parties' voluntary attempts to strive for settling a dispute in a consensual manner. This is particularly true for disputes of constitutive nature in which it is impossible to dismiss claims and the dispute can be settled in any case (cases of partition of joint ownership and inheritance, cases of access rights etc.). Ascertaining the features of such a dispute, the court must have the rights to order mediation if the parties have not yet engaged in it prior to claim submission to the court. Such a system has successfully been implemented in Finland (Taivalkoski and Pynnä: 2015). The use of mediation should be flexible providing both the parties involved and the court with an opportunity to settle the dispute prior to the court decision.

Human relationships cannot be characterized only as peaceful and harmonious because of the continuous emergence of disagreements, disputes and conflicts, which emerge as a result of a specific action or behavior. Criminal proceedings resolve specific types of conflicts. Article 1 of the Criminal Proceedings Law (Kriminālprocesa likums:2005) conveys the aim of the law, emphasizing the fact that the procedure of the criminal proceedings must be such that it can secure the effective application of rules of the Criminal Proceedings Law (Krimināllikums:1999) and the fair settlement of criminal law relations without unjustified interference into a person's life. The legislator has identified the fair settlement of a conflict that has emerged as a result of a criminal offence as one 
of the forms of the aim attainment.

One cannot forget that the criminal law conflict might be both true and seeming. It is exactly for this reason that no one can be considered guilty of a crime until his/her guit in commiting the offence has been proven with the framework of the Criminal Proceedings Law according to the set procedure. This aspect plays a paramount role in the European Parliament and Council Directive 2016/343 (9 March 2016), which ensures specific aspects of the presumption of innocence as well as the rights to participate in person in case hearings in court in the criminal proceedings (Directive (EU) 2016/343:2006). The Directive particularly emphasizes the importance of the EU member states' taking measures to ensure that in public announcements of public institutions and court decisions that do not pass on the guilty verdict on a person, the person-in-question be not mentioned as guilty.

The criminal law conflicts have quite different forms and contents; they are ambiuous and changeable. Therefore, it is implausible to conceive that there is just one universal form of conflict resolution for all conflicts. The resolution of the criminal law conflict in the form of reconcilliation in the Latvian criminal proceedings is most prominently manifested in the form of a settlement. The settlement as one of the forms of criminal law conflict resolution within the Latvian system of the Criminal Law has been accessible for some time; however, within the restorative justice context its application has started to increase only since 2005 when the specially trained mediators of the State Probation Service began to organize it.

Within the context of criminal proceedings, settlement is becoming more and more topical because its key objective is to eliminate the consequences that emerged as a result of the conflict, to compensate for the incurred damage and reconcile the parties involved. This is the way to simplify, speed up and increase the efficiency of the criminal procedure. This also reduces the number of tasks that otherwise would have to be completed if the case were to be investigated, procecuted and heard in court. It also provides victims with an opportunity to receive compensation for the incurred damage.

The American professor Hovard Zehr (Zehr: 2002), who is considered to be one of the founders of the concept of restoration of justice, indicated the key pillars of restoration of justice: focus on the offence and needs, offence creates duties and the involvement of the victim, offender and public in mitigation of consequences of the offence.

The focus of the settlement procedure is to reach agreement amongst the parties involved on the remedies of consequences of the offence, and therefore it does not matter if the settlement includes financial or moral compensation. According to the State Probation Service data on 2016, in 54\% of cases the settlement included financial compensation, 25\% were concluded with an apology and $9 \%$ ended up with both the financial and moral compensation. In other cases, the parties reached an agreement on moral compensation, financial compensation and works or just works, for example, fixing the damaged property (Pārskats:2016).

The settlement between the victim and the defendant can be recognized as legally binding if it is reached of free will, the defendant pleads guilty to the charges and the victim admits that from the moment of signing the settlement he/she will no longer have complaints against the defendant.

Settlement is within the victim's rights. The foundation of the settlement rests on the 
concept of restoration of justice when the victim and the offender are both involved in the elimination of consequences of the offence and reach an agreement on what is fair resolution of the conflict. The victim in the settlement process has an opportunity to express his/her opinion on what happened, receive answers to the questions that are of interest to him/her, receive apologies and compensation for the incurred losses, receive moral satisfaction and conviction that the offender has been forgiven and no further complaints are to be held against the offender.

There is a range of important differences between restoration of justice and contemporary criminal law. Firstly, the restoration of justice perceives the offence not only as violation of law, but also as the incurred damage for the victim, the public and self. Secondly, it involves more parties in the restoration of justice and does not assign the key role to the state and the offender.

The traditional contemporary criminal law has the tendency to alienate the parties involved in the conflict and entrust the conflict resolution to profesional lawyers as if restricting the access to justice for the persons involved. In contrast, within the framework of justice restoration, conflicts' resolution is returned to the parties involved and this ensures active participation of the victim and the offender in conflict resolution. Settlement exists only if the guilty party is ready to accept responsibility for the offence and plead guilty. The result of restoration of justice is also perceived differently - it is elimination of the consequences created by the conflict, compensation for the incurred damage un party reconciliation and not severity of criminal persecution (Judins:2015).

The main aims of settlement are to renew the public and personal safety, implement preventive measures, allow the guilty party to regret the committed offence, allow the guilty party to refrain from committing a new offence, allow the guilty party to become an example to other persons who are inclined to violate the law, forgive the abuse, allow the guilty party to realize personal mistakes and simplify operatons of the court system. Without attaining the above mentioned aims, settlement is only a formal action.

However, the consequences of a settlement in the criminal proceedings might be very different depending on the nature of the committed offence: 1) settlement as the condition unacceptable within the framework of the criminal proceedings (Section 9 of Article 377 of CPL); 2) settlement as foundation for the release of a person from criminal liability (Section 2 of Part 1 of Article 377 of CPL); 3) settlement that does not create the consequences for the termination of the criminal proceedings. This can serve as a condition for softening person's liability and punishment (Kaija:2015).

One important aspect relates to the necessity to fully clarify the provable conditions for the subject of proof during the criminal proceedings, especially, if it is only the pre-trial process. Would it be necessary to take procedural steps to clarify the presence or absence of elements of the committed offence and to clarify conditions provided for in the CL and CPL which play a role in the fair resolution of criminal legal relations if the victim and the suspect or the defendant have reached a settlement? In this case what is important to bear in mind is the fact termination of the criminal proceedings as a result of the achieved settlement is not a person's rehabilitation condition neither within the context of Article 377 of CPL nor Article 379 of CPL. Therefore, in all cases when settlement is the foundation for termination of the criminal proceedings the process facilitor cannot have reasonable doubts about the guilt in the committed offence of the 
person against which the criminal proceedings have been terminated. All doubts regarding the guilt that is impossible to eliminate must be considered for the benefit of the person who has the rights for defence. An additional guaranty has been provided by the requirements of Article 379 of CPL consistently with which if the decision for the release of a person from criminal liability has been made by the investigation officer, the approval of the state procesutor must be obtained.

The dispositive nature of the legal norms does not mean that the termination of the criminal proceedings has been decided by the process facilitator lawlessly. Considering the principles of the economy and humanism of the criminal proceedings, they must be terminated in all cases if the parties involved have announced their settlement regarding the commitment of the criminal offence or a lesser crime, except for cases when there are grounds to consider that the release of a person of both the criminal liability and punishment will not be fair and will not be in the public best interests. Furthermore, the decision of the process facilitor to continue or terminate the criminal proceedings should be justified and grounded in specific facts and circumstances (Judins:2010).

Settlement creates understanding about the roles of an individual and the public in limiting and combating crime as well as conflict resolution because it offers constructive solutions for the criminal justice that are not overly repressive.

\section{Conclusion and Implications}

Application of mediation in civil dispute resolution aims to fully protect rights of a right holder. Mediation allows the parties involved to deepen into the nature of the dispute. The key factor in the dispute resoluton is the will of the parties involved. In contrast to the judgement of the court, mediation is not grounded in the third party's (court's) conviction - it reflects the will of the parties involved, who have all the information about the roots of the dispute, the information on which is sometimes inaccessible to court and which the mediator can reveal when conducting mediation. Having analyzed the roots of the dispute first, have understood the causes of the dispute, the parties themselves can choose the best resolution for the dispute. Such a decision bears characteristics of dispute prevention. Such conflict resolution opportunities are particularly important when disputes relate to sensitive information, legal relations within the family, inheritance partition and co-ownership rights. Prior to bringing such types of disputes before the court, it is recommended that mediation be considered as a compulsive pre-trial stage, while simultaneously providing the court with more power to imply mediation. The development of the court recommended mediation in the civil proceedings, including the requirement of obligation, represent the prospects of the development of mediation.

Summarizing the above examined matter of settlement in the criminal proceedings, it is possible to conclude that in the settlement process the priority should be assigned to the rights of the victim, legal interests and views as well as providing the offender with an opportunity to compensate for the committed offence.

The mediator's role in the implementation of settlement is critical because it is exactly the knowledge, experience, values and attitudes of the mediator that represent the components of the professional competences that allow the parties to reach a result. The 
settlement reached with the assistance of a mediator is viewed as a strength of the criminal law which manifests in the fact that repressive punishment methods are not applied, the notion of impunity is not created, the interests of all the parties involved and impartiality and loyalty to all parties involved are observed, the decisions are made and the compensation for the incurred damage is paid based on the mutually reached consensus. The process of reaching the settlement must be conducted professionally, not formally, because the real indicator of settlement is the quality, not the quantity of settlements reached.

The key principles of settlements must be observed by all persons involved in ensuring the existence and progress of the settlement process, which also includes the law enforcement organizations, because this is how the negative consequences of the settlement proceedings are reduced and the positive aspects of settlement proceedings are secured, which overall develops positive attitudes in the public towards the notion of settlement.

The beneficiary party in the settlement case is also the entire Latvian court system because the legal costs of administering justice are reduced and so is the workload of judges and the case review time, the quality of judges' performance enhances and this creates the trust for the entire court system overall.

Because the history of implementation of settlement proceedings in Latvia is relatively short in comparison to other well-developed countries of the European Union, it is important to change deeply rooted stereotypes regarding the committed offences in that they are not only the problem and the competence of law-enforcement organizations they should be regarded as a solvable problem whose solution involves participation of various parties, such as law enforcement organizatoins, the parties directly involved in the offence and the public overall - it is the application of settlement practices that would allow to reach fair solutions within the criminal law context.

\section{References}

21.05.2008. Eiropas Parlamenta un Padomes direktīva Nr.2008/52/EK par konkrētiem mediācijas aspektiem civillietās un komerclietās. Publicēts: Eiropas Savienības oficiālais vēstnesis, 24.05.2008. Nr.L136/3

09.03.2016. Eiropas Parlamenta un Padomes Direktīva (ES) 2016/343 par to, lai nostiprinātu konkrētus nevainīguma prezumpcijas aspektus un tiesības piedalīties klātienē lietas izskatī̌̌anā tiesā kriminālprocesā. Publicēts: Eiropas Savienības oficiālais vēstnesis, 11.03.2016. Nr.L65/1

Civillikums. Ceturtā daḷa. Saistību tiesības. Latvijas Republikas likums. Stājies spēkā 01.03.1993. Publicēts: 26.02.1937. "Valdības Vēstnesis" Nr.46

Civilprocesa likums: Latvijas Republikas likums. Stājies spēkā 01.03.1999. Publicēts 03.11.1998. “ Latvijas Vēstnesis" Nr.326/330

Clark B. «Layers and Meditation», Berlin, Springer, 2012, S.169

Esplugues C. «Generel Report: New Developments in Civil and Commercial Mediation - Global Comparative Perspectives» no: New Developments in Civil and Commercial Mediation - Global Comparative Perspectives», Springer, 2015, S.2, S.15

Judins A. „Izlīgums Latvijas krimināltiesībās”, Rīga: Nordik, 2005. 11.lpp.

Judins A. Atjaunojošā justīcija nepilngadīgo noziedzības kontekstā: Baltijas valstis Eiropas dimensijā. Pieejams: http://politika.lv/article_files/1899/original/bez_sakumlapas_lv.pdf?1339440221 
Kaija S. Settlement in Resolution of Criminal Conflicts. In 2nd International Multidisciplinary Scientific Conference on Social Sciences and Arts SGEM2015, Book 2, Vol. 1, No. SGEM2015 Conference Proceedings, ISBN 978-619-7105-46-9 / ISSN 2367-5659. (2015), doi:10.5593/SGEMSOCIAL2015/B21/S5.085

Krimināllikums. Latvijas Republikas likums. 1998. gada 17. jūnijs, spēkā no 01.04.1999., Latvijas Vēstnesis Nr. 208 (3784)

Kriminālprocesa likums. Latvijas Republikas likums. 2005. gada 21. aprīlis, spēkā no 01.10.2005., Latvijas Vēstnesis Nr. 107 (3891)

Kudeikina I. «Mediācija kā nekustamā īpašuma kopīpašnieku strīdu pirmstiesas risināšanas instruments»,

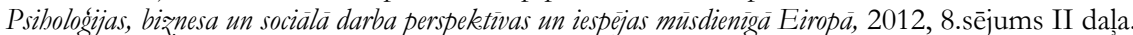

Mediācijas likums: Latvijas Republikas likums. Stājies spēkā 18.06.2014. Publicēts: 04.06.2014. " Latvijas Vēstnesis" Nr.108

Taivalkoski P. and Pynnä A. «The Courts and Bar Association as Drivers for Mediation in Finland» no New Developments in Civil and Commercial Mediation - Global Comparative Perspectives», Springer, 2015, S.280

Tiesu statistikas dati. Civillietas. Pieejams: https://www.ta.gov.lv/LV/publikacijas_un_statistika_1509 /statistikas_dati_58/civillietas_246 (aplūkots 30.03.2018.)

Tiesu statistikas dati. Krimināllietas. Pieejams: https://www.ta.gov.lv/LV/publikacijas_un_statistika_1509 /statistikas_dati_58/kriminallietas_245 (aplūkots 30.03.2018.)

Trosens, A., Vanaga, Z. Mediācija: izpratne un jēdziens latviešu valodā. Jurista värds, 2006, Nr. 29 (432). 9.lpp.

Valsts Probācijas dienesta 2016.gada publiskais pārskats. http://www.probacija.lv/upload /gada_parskati/2016_vpd_publiskais_parskats_master.pdf

Zehr. H. The little book of Restorative Justice, United States of America, Good Books, 2002., p. 22.,23.// http://www.unicef.org/tdad/littlebookrjpakaf.pdf

Аболонин В.О . «Судебная медиация», Москва, 2014, С.64, С.87

Аенисенко С.В. «Общеправовые проблемы медиации», Москва, 2010, С.39

Тихонова Е.А. «Некоторые выпросы интеграции примирительныйх процедур в гражАанский и арбитражный процесс», Альманах современной науки и образования, №4, 2013, С.188 